\title{
Privasi Yang Terpublikasi
}

\author{
Muhammad Akbar Fhad Syahril \\ Sekolah Tinggi IImu Hukum Amsir Parepare \\ Email: akbar9.a9@gmail.com
}

\begin{abstract}
Short messages that are advertisements are increasingly being received by the public through their cell phones. In fact, the public has never specifically given the phone number to the party sending the advertising message. This is considered to be increasingly annoying because the short message advertisements violate the principles of consumer protection. This study aims to determine and analyze the extent of privacy violations against the spread of spam information via short messages. This study uses a empirical normative method, namely research conducted with an approach to legal norms or substance, legal principles, legal postulates and legal comparisons, using a conceptual approach. The results showed that short messages in the form of offers that are not directly related to the services used by cellular subscribers should be a concern for the convenience of customers.
\end{abstract}

Keywords: Consumer protection; Violation of privacy; Send spam

\section{Latar Belakang Masalah}

Perkembangan media elektronik serta perkembangan kehidupan global mengakibatkan masyarakat Indonesia tentunya juga dituntut untuk menjadi masyarakat yang hidup lebih modern dengan adanya perkembangan kehidupan global yang serba maju dan serba modern dengan menggunakan berbagai alat elektronik dan jaringan internet yang tidak terbatas, peekambangan kehidupan global membawa arus yang cukup besar bagi kehidupan masyarakat Indonesia, salah satu yang marak ialah semakin berkembang pesatnya media sosial yang digunakan oleh masyarakat indonesia, media sosial yang sangat beragam, jenis serta kebutuhan yang ditawrkan kepada masyarakat Indonesia. ${ }^{1}$

Kejahatan penipuan yang dilakukan manusia melalui media elektronik merupakan kejahatan yang sering terjadi masa sekarang, sehingga kejahatan yang diterjadi tersebut hanya dapat dilakukan oleh orang-orang menguasai dan memahami teknnologi canggih, dan teknologi canggih tersebut yang mereka

\footnotetext{
${ }^{1}$ Tjandra Sridjaja Pradjonggo, 'Efektifitas Undang-Undang Nomor 11 Tahun 2008 Tentang Informasi Dan Transaksi Elektronik Terhadap Maraknya Pelanggaran Hukum Pidanapada Media Sosial', LIKHITAPRAJNA. Jurnal IImiah. Fakultas Keguruan Dan Ilmu Pendidikan, 15, 61-68.
} 
gunakan untuk melakukan tindak pidana penipuan, hal ini akan membuat banyak korban penipuan yang dimana korbanya kurang memahami dan menguasai teknologi atau media elektronik itu sehingga sulit untuk meminta pertanggung jawaban pelaku penipuan. ${ }^{2}$

Dalam Undang-undang Nomor 11 Tahun 2008 Tentang Informasi Transaksi Elektronik, hal tersebut menjadi titik awal baru dalam penggunaan media elektronik untuk mencegah tindak pidana dan dapat dijadikan pedoman didalam segala aktivitas elektonik. Regulasi tersebut akan memberikan ancaman pidana dan dapat mengurangi angka kejahatan penipuan ataupun teror iklan yang menjadi spam yang dapat melanggar hak privasi, yang tentunya menyesatkan.

Dengan berlakunya Undang-undang Nomor 11 Tentang Informasi Transaksi Elektronik, maka terciptalah suatu kajian baru dalam hukum menyangkut dunia maya yakni law in cyberspace tentunya keberadaan bidang baru ini berdampak pada perubahan hukum dalam hal perilaku kriminalisasi di dunia online. Dulu, sulit untuk membuktikan tindakan yang dapat membahayakan dunia online. Dengan adanya Undang-undang Nomor 11 tentang Informasi dan Transaksi Elektronik pada tahun 2008 niscaya sangat membantu. Industri teknologi Indonesia telah melakukan pelanggaran privasi dan etika dengan kata lain mempuplikasi privasi pelanggan. Privasi mulai terganggu. Ketika sering menerima pesan dari nomor ponsel, yang tidak teridentifikasi.

Penelitian ini merujuk dari beberapa contoh penelitian terdahulu sebagai panduan untuk penelitian yang dilakukan saat ini. Diambil berupa jurnal-jurnal diantaranya mengenai pentingnya memahami penerapan privasi di era teknologi informasi pada tulisan tersebut membahas mengenai perlindungan privasi (dalam berbagai bentuk), sangat penting dalam era internet saat ini dan juga tentunya sebagai pertimbangan penting bagi orang yang memilik tujuan untuk melakukan penelitian menggunakan Internet. Namun, perkembangan pesat dari masyarakat menyebabkan tantangan terkait dengan privasi karena meningkatnya kebutuhan pengungkapan diri pada tingkat interpersonal dan juga

\footnotetext{
${ }^{2}$ Ika Pomounda, 'Perlindungan Hukum Bagi Korban Penipuan Melalui Media Elektronik (Suatu Pendekatan Viktimologi)', Jurnal IImu Hukum Legal Opinion, 3 (2015).
} 
organisasi. Perlu adanya hukum-hukum khusus yang mengatur tentang privasi di Indonesia. Berbagai negara maju telah memiliki peraturan khusus tentang perlindungan data pribadi, namun hingga saat ini Indonesia belum mempunyai peraturan tersebut.

Kemudian jurnal mengenai Perlindungan Hukum Terhadap Privacy Dari Spamming Berdasarkan Undang-Undang Nomor 11 Tahun 2008 Tentang Informasi Dan Transaksi Elektronik, pada penelitian tersebut membahas mengenai Spamming sebagai perbuatan penyebaran pesan elektronik yang tidak diinginkan/diminta dan tanpa persetujuan penerimanya adalah melanggar privasi dan melawan hukum dalam bentuk penggunaan data pribadi tanpa persetujuan yang mengakibatkan kerugian. Spamming melanggar privasi pribadi seseorang karena setiap orang mempunyai hak untuk dibiarkan sendiri. Spamming juga melanggar privasi dari data personal, bahwa data tentang diri mereka sendiri tidak seharusnya secara otomatis tersedia untuk individu dan organisasi lainnya, dan dimana data tentang diri mereka dimiliki oleh orang lain, maka individu tersebut harus memiliki kontrol yang besar terhadap data tersebut berikut penggunaannya

Berangkat dari penelitian-penelitian sebelumnya, maka dianggap urgent dikaji lebih lanjut, diamana pemanfaatan media teknologi informasi dan komunikasi yang memberikan dampak positif tentunya pada sisi lain. Telah membuka kesempatan baru berupa fasilitas bagi para pelaku kejahatan untuk menggunakannya sebagai salah satu instrumen dalam melakukan kejahatan yang berdimensi dan modus baru di wilayah penggunaan teknologi informasi dan komunikasi. Pesan singkat atau Short Message Service yang bersifat iklan pinjaman online dan sejenisnya makin marak diterima masyarakat melalui perangkat telepon genggamnya. Padahal, masyarakat tidak pernah memberikan secara khusus nomor telepon kepada pihak yang mengirimkan pesan iklan tersebut. Kondisi ini dianggap semakin mengganggu karena pesan singkat iklan tersebut melanggar prinsip-prinsip perlindungan konsumen.

\section{Metode Penelitian}

Metode penelitian ini menggunakan penelitian normatif empiris, yakni penelitian yang dilakukan dengan pendekatan pada norma atau substansi hukum, dan perbandingan hukum. Penelitian hukum yang memadukan antara 
penelitian hukum normatif dan penelitian hukum sosial/empiris. Pada jenis penelitian semacam ini peneliti melakukan penelitian dengan mengkombain kedua tipe penelitian sebagaimana disebutkan diatas dalam sebuah penelitian. ${ }^{3}$ Pendekatan yang digunakan yakni pendekatan konseptual yang merupakan pendekatan yang memberi sudut pandang analisa terhadap penyelesaian permasalahan dalam penelitian hukum, yang dilihat dari aspek dan konsep-konsep hukum yang melatarbelakanginya, bahkan bisa juga dilihat dari nilai-nilai yang terkandung dalam penormaan sebuah peraturan yang sekaitan dengan konsep-konsep yang digunakan. Penelitian yang dilakukan bersifat deskriptif analitis yaitu menggambarkan, menganalisis, menyimpulkan masalah-masalah yang menjadi objek penelitian.

\section{Analisis Dan Pembahasan}

\section{Pelanggaran Terhadap Penyebaran Informasi Spam Melalui Pesan Singkat}

Pada zaman modern ini kita diberi kemudahan, tentunya dengan banyak manfaat yang dapat diperoleh dari kemajuan teknologi saat ini. Penggunaan teknologi informasi juga ikut mengalami perkembangan pesat, seperti pada bidang komunikasi. Saat ini komunikasi beralih menjadi suatu hal kompleks yang dapat mengubah perilaku manusia.

Kemajuan teknologi informasi perlu diimbangi dengan tersedianya perangkat legal untuk mencegah New Crimes, Frauds, dan Negative Externalities. ${ }^{4}$ Masyarakat telah memanfaatkan teknologi dalam kehidupan sehari-hari, salah satunya teknologi informasi dan komunikasi berupa media elektronik lainnya. Selain memiliki dampak positif yang besar, teknologi informasi dan komunikasi juga memiliki sisi negatif. Berbagai kejahatan dapat dilakukan dengan menggunakan teknologi informasi pencurian data-data perusahaan lewat internet dan penipuan melalui media elektronik. Oleh sebab itu diperlukan hukum untuk mengaturnya. ${ }^{5}$

Hampir semua konsumen atau pelanggan seluler mendapat spam pesan singkat. Dengan tidak adanya persetujuan lebih dulu dari konsumen mengenai

\footnotetext{
${ }^{3}$ Syahruddin Nawi, Penelitian Hukum Nomorrmatif Versus Penelitian Hukum Empiris, 5th edn (Makassa: PT.Umitoha Ukhuwah Grafika, 2017).

${ }^{4}$ Maskun, Hukum Dan Teknologi, 2021.

${ }^{5}$ O.C. Kaligis, Penerapan Undang-Undang Nomor 11 Tahun 2008 Tentang Informasi Dan Transaksi Elektronik Dalam Prakteknya (Jakarta: Yarsif Watampone, 2008).
} 
ketersediaan menerima pesan singkat iklan tersebut. Istilah Don't Call Register, yang berarti pihak jasa telekomunikasi tidak diperkenankan mengirim pesan singkat baik itu berupa penawaran kepada pelanggan yang sudah menyatakan tidak setuju dikirimi pesan singkat penawaran dari pihak jasa komunikasi ataupun seperti pinjaman online yang sifatnya spam.

Undang-undang pada awalnya melindungi kepentingan negara, masyarakat, dan sektor swasta dari cybercrime. Kemudian ada tiga kategori yang mencakup undang-undang, yang sekaitan dengan penghinaan, penghujatan, dan ancaman online. Hukum menjerat tidak hanya penulis tetapi juga mereka yang mendistribusikan, mentransmisikan, atau membuat konten dapat diakses secara elektronik. ${ }^{6}$ Selain konten juga terdapat data yang berifat privasi. Data dapat dikatakan data pribadi jika pada data tersebut dapat digunakan untuk mengenali atau mengidentifikasi seseorang. Privacy merupakan kemampuan satu atau sekelompok individu untuk mempertahankan kehidupan dan urusan personalnya dari publik, yang mana seseorang mengontrol arus informasi mengenai diri sendiri. Penggambaran lainnya mengenai privasi merupakan suatu hak individu untuk menentukan sejauh mana dan apakah seseorang bersedia membuka dirinya kepada orang lain. ${ }^{7}$

Pada penerapan peraturan perundang-undangan yang mengatur mengenai masalah transaksi elektronik melalui Undang-undang Nomor 11 Tahun 2008 Tentang Informasi Dan Transaksi Elektronik, mulai dari awal undang-undang ini diundangkan dan sampai dengan sekarang, memang terlihat bahwa penerapan undang-undang ini dirasa efektif terhadap hukum, yang tidak terlepas dari permasalahan penegakan hukum yang merupakan suatu proses yang melibatkan banyak hal. Olehnya itu keberhasilan penegakan hukum tentunya sangat dipengaruhi oleh hal-hal tersebut, sedikitnya terdapat beberapa faktor yang mempengaruhi penegakan hukum, diantaranya sebagai berikut:

a. Faktor hukumnya sendiri.

b. Faktor petugas sebagai penegak hukum, yaitu pihak-pihak yang membentuk maupun yang menerapkan hukum

\footnotetext{
${ }^{6}$ Andysah Putera Utama Siahaan, 'Pelanggaran Cybercrime Dan Kekuatan Yurisdiksi Di Indonesia', $\begin{array}{lllll}\text { Jurnal Teknik Dan } & 5.1 & \text { (2018), }\end{array}$ <http://jurnal.pancabudi.ac.id/index.php/Juti/article/view/82>.

${ }^{7}$ Witri. Joni Andre Ramadhani, ‘Pentingnya Memahami Penerapan Privasi Di Era Teknologi Dan Informasi', Jurnal Teknologi Komunikasi Dan Pendidikan, 12.1 (2019), 4.
} 
c. Faktor sarana atau fasilitas yang mendukung penegakan hukum.

d. Faktor masyarakat, yakni lingkungan di mana hukum tersebut berlaku atau diterapkan. Dan terakhir

e. Faktor kebudayaan, yaitu sebagai hasil karya, cipta, dan rasa yang didasarkan pada karsa manusia di dalam pergauan hidup. ${ }^{8}$

Kesalahannya ialah karena menyebarkan informasi dan dokumen elektronik kepada banyak orang atau berbagai pihak baik itu melalui pesan singkat maupun jaringan internet. Pesan singkat berisi iklan yang dikirim tanpa persetujuan terlebih dahulu dari pemilik nomor, tentunya telah melanggar Pasal 26 Undang-undang Nomor 19 Tahun 2016 Tentang Perubahan Atas Undang-Undang Nomor 11 Tahun 2008 Tentang Informasi Dan Transaksi Elektronik. Di dalam pemanfaatan teknologi informasi, pentingnya perlindungan terhadap data pribadi yang merupakan salah satu bagian dari hak pribadi. Hak pribadi dimaksud diuraikan sebagai berikut:

a. Hak pribadi merupakan hak untuk menikmati kehidupan pribadi dan bebas dari segala macam gangguan.

b. Hak pribadi merupakan hak untuk dapat berkomunikasi dengan Orang lain tanpa tindakan memata-matai.

c. Hak pribadi merupakan hak untuk mengawasi akses informasi tentang kehidupan pribadi dan data seseorang.

Selain hak pribadi, juga ada hak asasi manusia yang sekaitan dengan perlindungan data, terdapat hak dasar yang menjadi landasan adanya hak asasi manusia itu sendiri, yaitu hak atas privasi. Pernyataan ini sejalan dengan konsep hak asasi manusia itu sendiri yang dibangun di atas privasi sebagai dasarnya. ${ }^{9}$

Perlindungan data juga merupakan hak asasi manusia yang fundamental. Dimana beberapa negara telah mengakui perlindungan data sebagai suatu hak konstitusional yakni hak seseorang untuk mendapatkan pengamanan terhadap data yang dimilikinya dan untuk pembenaran ketika ditemukan kesalahan terhadap datanya. ${ }^{10}$ Jika terjadi penggunaan data pribadi seseorang tanpa izin

\footnotetext{
${ }^{8}$ Soerjono Soekanto, Fakto-Faktor Yang Mempengaruhi Penegakan Hukum. Cet. 5 (Raja Grafindo Persada, 2004).

${ }^{9}$ Anjas Putra Pramudito, 'Kedudukan Dan Perlindungan Hak Atas Privasi Di Indonesia', Jurist-Diction, 3 (2020).

${ }^{10}$ Sinta Dewi, 'Konsep Perlindungan Hukum Atas Privasi Dan Data Pribadi Dikaitkan Dengan Penggunaan Cloud Computing Di Indonesia', Yustisia Jurnal Hukum, 5.1 (2016), 22-30
} 
dari orang yang bersangkutan, maka orang yang dilanggar haknya itu dapat mengajukan gugatan atas kerugian yang ditimbulkan. Sedangkan, hal yang berkaitan dengan penjabaran tentang data elektronik pribadi, Undang-undang Informasi dan Transaksi Elektornik mengamanatkannya lagi dalam Peraturan Pemerintah Nomor 71 Tahun 2019 tentang Penyelenggaraan Sistem dan Transaksi Elektronik.

Definisi data pribadi terdapat dalam Pasal 1 angka 29 Peraturan Pemerintah Nomor 82 Tahun 2012 tentang Penyelenggaraan Sistem dan Transaksi Elektronik. Juga pada Pasal 1 Peraturan Pemerintah Nomor 82 Tahun 2012 tentang Penyelenggaraan Sistem dan Transaksi Elektronik. Perlindugan data pribadi tentunya merupakan suatu hal yang penting bagi konsumen itu sendiri dalam melakukan transaksi online sebab data pribadi tersebut berhubungan dengan keamanan konsumen itu sendiri. Karena posisi konsumen yang lemah maka ia harus dilindungi oleh hukum. ${ }^{11}$

Perlindungan data pribadi dalam sebuah sistem elektronik meliputi perlindungan dari penggunaan tanpa izin, perlindungan oleh penyelenggara sistem elektronik, dan perlindungan dari akses dan interferensi ilegal. Terkait dengan perlindungan data pribadi dari penggunaan tanpa izin, Pasal 26 Undang-undang Informasi Dan Transaksi Elektronik mensyaratkan bahwa penggunaan setiap data pribadi dalam sebuah media elektronik harus mendapat persetujuan pemilik data bersangkutan. ${ }^{12}$

Dalam Undang-undang Nomor 11 Tahun 2008 Tentang Informasi Dan Transaksi Elektronik Pasal 26 menegaskan bahwa:

a. Penggunaan setiap informasi melalui media elektronik yang menyangkut data pribadi seseorang harus dilakukan atas persetujuan orang yang bersangkutan.

b. Setiap Orang yang dilanggar haknya sebagaimana dimaksud pada ayat (1) dapat mengajukan gugatan atas kerugian yang ditimbulkan berdasarkan Undang-Undang ini

<https://doi.org/https://doi.org/10.20961/yustisia.v5i1.8712>.

${ }^{11}$ Celina Tri Siwi Kristiyanti, Hukum Perlindungan Konsumen (Jakarta: Sinar Grafika, 2011).

${ }^{12}$ Rosalinda Elsina Latumahina, 'Aspek Hukum Perlindungan Data Pribadi Di Dunia Maya', 3.2 (2014), 14-25. 
Dalam penjelasannya, Pasal 26 Undang-undang Informasi Dan Transaksi Elektronik menegaskan bahwa data pribadi merupakan salah satu bagian dari hak pribadi seseorang. Jika dilihat dari konteks hukum, maka privasi merupakan suatu hak Right To Be Let Alone. Sedangkan pedoman hukum Indonesia dalam menjaga privasi bersumber dari Undang-undang Teknologi Informasi ayat 19 yang menyatakan bahwa privasi merupakan suatu hak individu untuk mengendalikan penggunaan informasi tentang identitas pribadi baik oleh dirinya sendiri atau oleh pihak lainnya.

Badan Regulasi Telekomunikasi Indonesia sebagai suatu lembaga memiliki wewenang dalam mengatur standar kualitas terhadap layanan harus bertindak cepat dan tegas. Setidaknya dengan Badan Regulasi Telekomunikasi Indonesia kemudian bisa mengikuti aturan yang diterapkan Otoritas Jasa Keuangan dalam memperlakukan konsumen penerima layanan jasa keuangan. Otoritas Jasa Keuangan membatasi pelaku usaha keuangan yang dalam menyampaikan informasi melalui pesan singkat kepada para konsumen, hanya bisa dilakukan pada hari Senin sampai dengan Sabtu, diluar hari-hari libur nasional.

Spamming sebagai suatu pengiriman informasi untuk menampilkan berita iklan dan keperluan lainnya yang berakibatk pada ketidaknyamanan para pengguna. Spam biasanya datang tanpa diminta dan sering kali tidak dikehendaki oleh penerimanya. Spamming dapat menimbulkan dampak atau kerugian bagi penerimanya baik itu immateriil maupun materiil. Spamming tentunya dapat mengganggu privasi, yang mana nomor handphone sama seperti alamat tempat tinggal. Pada saat ada informasi dari seseorang tidak dikenal yang mengunjungi tempat tinggal kita tanpa diminta, dan tidak pernah memberikan persetujuan, barang tentu membuat kita menjadi sangat tidak nyaman. Spamming melanggar privasi karena mengirimkan informasi yang mengganggu privasi, berupa informasi yang tidak dikehendaki dan juga melanggar property. Pelanggaran terhadap privasi yang dimaksud berkaitan dengan dimensi dan aspek dari privasi itu sendiri. ${ }^{13}$

Dengan adanya tindakan pelaku usaha jasa telekomunikasi tersebut telah melanggar Pasal 23 ayat 2 huruf a dan b Permenkominfo Nomor 9 tahun 2017

\footnotetext{
${ }^{13}$ Tansah Rahmatullah, 'Perlindungan Hukum Terhadap Privacy Dari Spamming Berdasarkan Undang-Undang No. 11 Tahun 2008 Tentang Informasi Dan Transaksi Elektronik', Jurnal Hukum Media Justitia Nusantara, 4.11 (2015), 102-23 <http://ojs.uninus.ac.id/index.php/MJN/article/view/222>.
} 
Tentang Penyelengaraan Jasa Penyediaan Konten Pada Jaringan Bergerak Seluler. Sedangkan untuk hukuman dan pidana tentang privasi juga sudah cukup jelas pada Pasal 29 yang menegaskan mengenai pelanggaran hak privasi dengan hukuman paling singkat 3 tahun dan paling lama 7 tahun.

Setiap data tentunya memiliki nilai, entah berupa nilai pribadi, nilai strategis ataupun nilai ekonomis yang bisa untuk diukur dengan uang bagi seseorang atau bahkan organisasi. Disamping itu, data bersifat sensitif, penambahan, atau pengurangan, perubahan data dapat berdampak cukup besar terhadap integritas suatu data. Semakin besar nilai data, maka akan semakin penting adanya perlindungan terhadap data tersebut. Tujuan perlindungan data ialah untuk menjaga serta melindungi confidentiality, integrity, accessibility karena pada prinsipnya hanya orang yang memiliki hak yang dapat mengakses informasi termasuk mengubah, menambah, mengurangi, ataupun menghilangkan data. ${ }^{14}$

Secara sederhana diartikan bahwa terhadap pelanggaran privasi merupakan suatu bentuk penyalahgunaan akses terhadap data pribadi milik pelanggan atau orang lain yang melawan hukum yang mengganggu hak privasi individu dengan cara menyebarkan data pribadi tanpa seizin yang bersangkutan. Pada intinya Kementerian Komunikasi dan Informatika seharusnya menerbitkan regulasi yang melindungi privasi dan hak konsumen untuk menolak pesan singkat berbentuk spam atau iklan yang mengganggu.

Badan Regulasi Telekomunikasi Indonesia harus mengatur tentang pemberian keleluasaan kepada konsumen untuk tidak menyetujui layanan, mengatur larangan penawaran via pesan singkat dan atau batasan konten yang termasuk dalam layanan penawaran, batasan waktu penawaran kepada konsumen yang menyetujui menerima pesan singkat serta ditetapkannya suatu sanksi atas pelanggaran aturan tersebut.

Ketentuan Undang-Undang Nomor 8 Tahun 1999 Tentang Perlindungan Konsumen Pasal 4, konsumen memilki hak sebagai berikut:

a. Hak atas kenyamanan, keamanan, dan keselamatan dalam mengkonsumsi barang atau jasa.

\footnotetext{
${ }^{14}$ Josua Sitompul, Cyberspace, Cybercrimes, Cyberlaw: Tinjauan Aspek Hukum Pidana (Jakarta: Tatanusa, 2012).
} 
b. Hak untuk memilih barang dan/atau jasa, serta mendapatkan barang dan/atau jasa tersebut sesuai dengan nilai tukar dan kondisi, serta jaminan yang dijanjikan.

c. Hak atas informasi yang jelas, dan jujur mengenai kondisi dan jaminan barang dan/atau jasa.

d. Hak untuk didengar pendapat dan keluhannya atas barang dan/atau jasa yang digunakan.

e. Hak untuk mendapatkan advokasi, perlindungan, dan upaya penyelesaian sengketa perlindungan konsumen secara patut.

f. Hak untuk mendapat pembinaan dan pendidikan konsumen.

g. Hak untuk diperlakukan atau dilayani secara benar, jujur serta tidak diskriminatif.

h. Hak untuk mendapatkan kompensasi, ganti rugi atau penggantian, apabila barang dan/atau jasa yang diterima tidak sesuai dengan perjanjian atau tidak sebagaimana mestinya.

i. Hak-hak yang diatur dalam ketentuan peraturan perundang-undangan lainnya. ${ }^{15}$

Jelas bahwa masalah kenyamanan, keselamatan, dan keamanan konsumen merupakan hal utama dalam perlindungan konsumen. Barang atau jasa yang penggunaannya tidak memberikan kenyamanan, terlebih lagi rasa tidak aman yang dapat membahayakan keselamatan konsumen jelaslah tidak layak untuk diedarkan dalam masyarakat. Kemudian untuk dapat menjamin bahwa barang atau jasa dalam penggunaannya tersebut nyaman, aman maupun tidak membahayakan konsumen penggunanya, maka konsumen diberikan hak untuk memilih barang atau jasa yang diinginkan berdasar atas keterbukaan informasi yang jelas, benar, dan jujur. Jika terdapat penyimpangan yang merugikan, konsumen berhak untuk didengar, memperoleh advokasi, pembinaan, perlakuan yang adil, kompensasi sampai ganti rugi. ${ }^{16}$

\footnotetext{
${ }^{15}$ Gunawan Widjaja, Hukum Tentang Perlindungan Konsumen (Jakarta: Gramedia Pustaka Utama, 2000).

${ }^{16}$ Novanema Duha, T Azwar, And Windha Windha, 'Penipuan Short Message Service (SMS) Terhadap Konsumen Provider Telepon Seluler Ditinjau Dari Undang-Undang Nomor 8 Tahun 1999 Tentang Perlindungan $\quad$ Konsumen', $\quad$ Transparency, $\quad 2.1 \quad$ (2013) <https://media.neliti.com/media/publications/14661-ID-penipuan-short-message-service-sms-terhadapkonsumen-provider-telepon-seluler-di.pdf>.
} 
Seperti halnya pada kasus yang sudah sangat lama mengganggu masyarakat selaku konsumen. Maraknya pesan singkat yang masuk ke nomor telpon genggamn para konsumen berupa iklan pinjaman online dari nomor yang tidak diketahui, padahal masyarakat sama sekali tidak pernah memberi secara khusus nomor telepon kepada pihak yang mengirimkan pesan iklan tersebut, ataupun memberikan izin kepada operator seluler untuk mengizinkan sipengirim pesan iklan yang kemudian menjadi spam. Sangatlah disayangkan karena kemudian kondisi ini diarasa mengganggu, dimana bukan hanya sekali tetapi bisa lima sampai sepuluh pesan serupa dari nomor berbeda dalam sehari yang diterima para konsumen, dan spam tersebut tentunya sangat melanggar prinsip-prinsip dalam perlindungan konsumen.

Jika ditelaah Undang-undang Nomor 8 Tahun 1999 Tentang Perlindungan Konsumen Pasal 29 ayat 1 yang menegaskan bahwa pemerintah tentunya bertanggungjawab atas pembinaan penyelenggaraan perlindungan konsumen yang menjamin diperolehnya hak konsumen dan para pelaku usaha serta dilaksanakannya kewajiban konsumen dan pelaku usaha. ${ }^{17}$ Lebih lanjut pembinaan terhadap para konsumen bertujuan agar supaya para konsumen bisa mengetahui hak-haknya sebagai konsumen dalamhalini pelanggan seluler. Dalam era kemajuan teknologi pada saat ini, pembinaan konsumen harus dapat ditingkatkan mengingat bahwa pendidikan dan pelatihan konsumen sebagai upaya dalam melindungi konsumen dari penipuan melalui pesan suingkat.

Sementara Badan Regulasi Telekomunikasi Indonesia dalam situsnya pada pertengahan 2020 lalu menyatakan menerima segala bentuk aduan konsumen yang sering menerima pesan singkat penipuan dan iklan tersebut. Badan Regulasi Telekomunikasi Indonesia menyatakan pihaknya menerima segala bentuk laporan masyarakat pesan atau panggilan yang mengganggu dan tentunya tidak dikehendaki seperti permintaan untuk mentrasfer uang, pesan pemenang kuis atau undian, judi online, maupun pinjaman uang yang masuk melalui pesan singkat dari nomor-nomor yang tidak dikenal.

\section{Penutup}

Pelanggaran privasi merupakan salah satu bentuk penyalahgunaan akses

\footnotetext{
${ }^{17}$ Happy Susanto, Hak-Hak Konsumen Jika Dirugikan, Cetakan Pertama (Jakarta: Visimedia, 2008).
} 
data pribadi orang lain yang melawan hukum yang mengganggu hak privasi individu dengan cara menyebarkan data pribadi tanpa seizin yang bersangkutan. Seperti halnya pesan singkat, berupa penawaran yang tidak berkaitan secara langsung dengan layanan yang digunakan oleh pelanggan atau sifatnya spam, oleh operator seharusnya menjadi perhatian, terutama menyangkut kenyamanan pelanggan, seperti halnya kesediaan pelanggan untuk mau atau tidak menerima pesan singkat penawaran yang demikian atau dengan kata lain spam

\section{Referensi}

Anjas Putra Pramudito, 'Kedudukan Dan Perlindungan Hak Atas Privasi Di Indonesia', Jurist-Diction, 3 (2020)

Duha, Novanema, T Azwar, And Windha Windha, 'Penipuan Short Message Service (Sms) Terhadap Konsumen Provider Telepon Seluler Ditinjau Dari Undang-Undang Nomor 8 Tahun 1999 Tentang Perlindungan Konsumen', Transparency, $2.1 \quad$ (2013) $<$ Https://Media.Neliti.Com/Media/Publications/14661-Id-PenipuanShort-Message-Service-Sms-Terhadap-Konsumen-Provider-Telep on-Seluler-Di.Pdf>

Happy Susanto, Hak-Hak Konsumen Jika Dirugikan, Cetakan Pertama (Jakarta: Visimedia, 2008)

Ika Pomounda, 'Perlindungan Hukum Bagi Korban Penipuan Melalui Media Elektronik (Suatu Pendekatan Viktimologi)', Jurnal IImu Hukum Legal Opinion, 3 (2015)

Kristiyanti, Celina Tri Siwi, Hukum Perlindungan Konsumen (Jakarta: Sinar Grafika, 2011)

Latumahina, Rosalinda Elsina, 'Aspek Hukum Perlindungan Data Pribadi Di

Dunia Maya', 3.2 (2014), 14-25

Maskun, Hukum Dan Teknologi, 2021

Nawi, Syahruddin, Penelitian Hukum Nomorrmatif Versus Penelitian Hukum Empiris, 5th Edn (Makassa: Pt.Umitoha Ukhuwah Grafika, 2017)

O.C. Kaligis, Penerapan Undang-Undang Nomor 11 Tahun 2008 Tentang Informasi Dan Transaksi Elektronik Dalam Prakteknya (Jakarta: Yarsif Watampone, 2008)

Pradjonggo, Tjandra Sridjaja, 'Efektifitas Undang-Undang Nomor 11 Tahun 
2008 Tentang Informasi Dan Transaksi Elektronik Terhadap Maraknya Pelanggaran Hukum Pidanapada Media Sosial', Likhitaprajna. Jurnal IImiah.Fakultas Keguruan Dan IImu Pendidikan, 15, 61-68

Rahmatullah, Tansah, 'Perlindungan Hukum Terhadap Privacy Dari Spamming Berdasarkan Undang-Undang No. 11 Tahun 2008 Tentang Informasi Dan Transaksi Elektronik', Jurnal Hukum Media Justitia $\begin{array}{lll}\text { Nusantara, } & 4.11 & \text { (2015), }\end{array}$

$<H$ ttp://Ojs.Uninus.Ac.Id/Index.Php/Mjn/Article/View/222>

Ramadhani, Witri. Joni Andre, 'Pentingnya Memahami Penerapan Privasi Di Era Teknologi Dan Informasi', Jurnal Teknologi Komunikasi Dan Pendidikan, 12.1 (2019), 4

Sinta Dewi, 'Konsep Perlindungan Hukum Atas Privasi Dan Data Pribadi

Dikaitkan Dengan Penggunaan Cloud Computing Di Indonesia', Yustisia Jurnal Hukum, $5.1 \quad$ (2016), 22-30 <Https://Doi.Org/Https://Doi.Org/10.20961/Yustisia.V5i1.8712>

Sitompul, Josua, Cyberspace, Cybercrimes, Cyberlaw: Tinjauan Aspek Hukum Pidana (Jakarta: Tatanusa, 2012)

Soerjono Soekanto, Fakto-Faktor Yang Mempengaruhi Penegakan Hukum.

Cet. 5 (Raja Grafindo Persada, 2004)

Utama Siahaan, Andysah Putera, 'Pelanggaran Cybercrime Dan Kekuatan Yurisdiksi Di Indonesia', Jurnal Teknik Dan Informatika, 5.1 (2018), 6-9 <Http://Jurnal.Pancabudi.Ac.Id//ndex.Php/Juti/Article/View/82> Widjaja, Gunawan, Hukum Tentang Perlindungan Konsumen (Jakarta: Gramedia Pustaka Utama, 2000)

\section{Peraturan Perundang-Undang}

Undang-Undang Nomor 19 Tahun 2016 Tentang Perubahan Atas Undang-Undang Nomor 11 Tahun 2008 Tentang Informasi Dan Transaksi Elektronik

Undang-Undang Nomor 8 Tahun 1999 Tentang Perlindungan Konsumen

Peraturan Pemerintah Nomor 82 Tahun 2012 tentang Penyelenggaraan Sistem dan Transaksi Elektronik 
Peraturan Menteri Komunikasi dan Informasi Nomor 9 tahun 2017 tentang Penyelengaraan Jasa Penyediaan Konten Pada Jaringan Bergerak Seluler 